\title{
Nearshore ecosystem predictors of a bacterial infection in juvenile Chinook salmon
}

\author{
Linda D. Rhodes ${ }^{1, *}$, Casimir A. Rice ${ }^{1}$, Correigh M. Greene ${ }^{1}$, David J. Teel ${ }^{2}$, \\ Shelly L. Nance ${ }^{1,3}$, Paul Moran ${ }^{1}$, Colleen A. Durkin ${ }^{1,4}$, Surafel B. Gezhegne ${ }^{1,5}$ \\ ${ }^{1}$ NOAA Fisheries, Northwest Fisheries Science Center, 2725 Montlake Boulevard East, Seattle, Washington 98112, USA \\ ${ }^{2}$ NOAA Fisheries, Northwest Fisheries Science Center, Manchester Research Laboratory, 7305 East Beach Drive, \\ Port Orchard, Washington 98366, USA \\ ${ }^{3}$ Present address: Aquatic and Fisheries Sciences, Box 355020, University of Washington, Seattle, Washington 98195, USA \\ ${ }^{4}$ Present address: School of Oceanography, Box 357940, University of Washington, Seattle, Washington 98195, USA \\ ${ }^{5}$ Present addresss: Internal Medicine Residency Program, Loma Linda University Medical Center, 11234 Anderson Street, \\ Loma Linda, California 92354, USA
}

\begin{abstract}
Disease epidemiology requires information about ecological and environmental conditions to identify factors that can influence disease progression. Bacterial kidney disease (BKD) is an endemic disease among Pacific Northwest salmonids that causes significant morbidity and mortality in artificially propagated stocks, but risk factors for infection among free-living salmon are unknown. We evaluated infection by the causative agent of BKD, Renibacterium salmoninarum, in 1752 fish across 52 sampling sites monthly from May to November 2003 as a component of a broader study of neritic habitat use in Puget Sound by juvenile Chinook salmon Oncorhynchus tshawytscha. Infection intensity was $\leq 10$ cells per slide for $77 \%$ of the fish. Correlations between the density of Chinook salmon with infection prevalence and with infection intensity were observed across multiple spatial scales. Capture location was a stronger predictor of infection than fish origin (based on coded wire tags) or genetic stock. Influential risk factors by logistic regression were temperature, densities of marked and unmarked Chinook salmon, and density of river lamprey Lampetra ayresis. Renibacterium salmoninarum were found in gut contents and kidney of river lamprey, suggesting this species may be a transmission vector. The low infection intensity, lack of an effect of fish origin, effect of capture bay, and strong associations with Chinook salmon density are consistent with horizontal transmission of $R$. salmoninarum during the juvenile neritic phase, posing a potential for infectious interaction between sympatric hatchery and wild fish.
\end{abstract}

KEY WORDS: Chinook salmon $\cdot$ Bacterial infection $\cdot$ Risk factor $\cdot$ Horizontal transmission Resale or republication not permitted without written consent of the publisher

\section{INTRODUCTION}

Disease is often cited as an important element in conservation biology, and models describing the limitations that disease can exert on host populations have been formally described since the 1970s (Anderson \& May 1978). Disease can disrupt ecosystem processes such as trophic relationships when a keystone species is affected (Mumby et al. 2006, Johnson et al. 2009), or it can threaten small or isolated populations with extinction (e.g. Clifford et al. 2006). Conversely, information about environmental and ecological conditions surrounding disease occurrences can provide critical information about factors that influence disease progression, such as pathogen reservoirs (Haydon et al. 2002). Nonetheless, disease surveillance is uncommon in population or ecosystem monitoring. In the Pacific Northwest, 17 federal conservation units of Pacific salmon have been designated as threatened or endangered (Good et al. 2007), stimulating a range of recov- 
ery strategies including captive rearing efforts to rebuild a particular stock (Pollard \& Flagg 2004). In addition, an extensive hatchery system for Pacific salmon was developed over the last 100 years, annually releasing more than 100 million salmon and steelhead juveniles into Puget Sound and coastal Washington rivers (Mobrand et al. 2005). In the course of artificial propagation, diseases that are poorly documented in feral populations can emerge as serious epizootics or debilitating chronic pathologies (Daszak et al. 2000, Montali et al. 2001). In addition to the impact of diseases on propagated populations, the potential for transmission of infectious agents between captively reared and wild (or natural origin) fish is a broad concern for fish culture and conservation (McVicar et al. 2006).

One of the most common and debilitating diseases among propagated Pacific Northwest salmon is bacterial kidney disease (BKD), which is caused by the Gram-positive bacterium Renibacterium salmoninarum. Infection by $R$. salmoninarum can cause acute morbidity and mortality, or it can result in chronically infected, asymptomatic carriers. Transmission can occur vertically by intra-ovum transfer (Evelyn et al. 1986a,b) and horizontally through a presumptive oralfecal route (Balfry et al. 1996) or through breaks in the skin (Elliott \& Pascho 2001). Efforts to control and reduce infection in hatcheries rely on antibiotic injections of broodstock and culling eggs from females with elevated levels of bacterial proteins in kidney tissue. Monitoring juvenile salmon during the freshwater phase has provided evidence that $R$. salmoninarum infection is endemic in Pacific Northwest watersheds (Sanders et al. 1992, Pascho et al. 1993, VanderKooi \& Maule 1999, Arkoosh et al. 2004). Less is known about the infection status in seawater (Meyers et al. 1999, Bruno 2004, Rhodes et al. 2006), especially during the early marine phase, a transition period between freshwater and ocean residence that is considered to be the most critical period in determining survival to adulthood (Pearcy 1992). The present study addressed 2 objectives. First, we wished to determine the prevalence and intensity of infection among juvenile Chinook salmon during the first few months in seawater. Second, we wanted to identify biotic and abiotic risk factors for infection among recently emigrated fish. These objectives were chosen to address the lack of information about the distribution of infection and its potential impact on endangered stocks of Chinook salmon. This effort was a component of a larger monitoring study to assess nearshore marine habitat use in Puget Sound by juvenile Chinook salmon (Rice et al. 2011), which allows the infection results to be examined within a broader ecological context.

\section{MATERIALS AND METHODS}

Study area and sampling efforts. The study area encompassed northern Puget Sound and the eastern portion of the main and southern basins of Puget Sound (Fig. 1; see Rice et al. 2011 for site selection rationale). We sampled each of the 52 sites once per month from April through November in 2003, and each monthly sampling consisted of 2 successive tows employing a Kodiak surface trawl as described by Rice et al. (2011). For each tow, water temperature and salinity were measured at a depth of approximately $1.2 \mathrm{~m}$, and the depth of the tow was recorded. Fish catch from each tow was counted by species. Fish densities were calculated by dividing the raw catch with the area swept by the trawl. Gelatinous zooplankton (jellyfish) were combined and weighed. For the taxonomic composition of the catch, see Rice et al. (2011). For individual Chinook salmon, we measured the fork length, examined visually for fin clips, and checked for a coded wire tag (CWT) by using a handheld detector

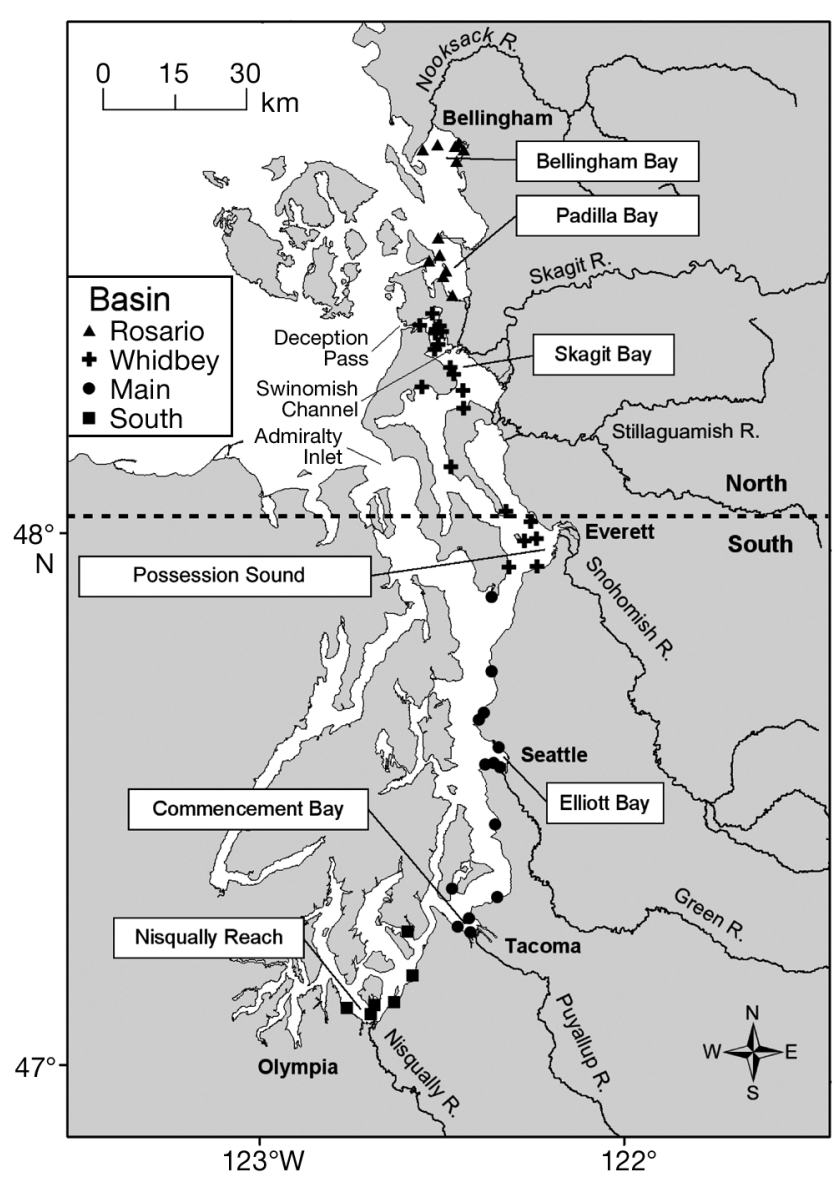

Fig. 1. Locations of sites sampled in this study and aggregate assignments by bay (labels within boxes), by basin (symbols), and by area (separated by dotted line) 
(Northwest Marine Technologies). A total of 1752 Chinook salmon for infection analysis were collected in 668 tows over the sampling period. Collection efforts yielded only 1 fish in April and 5 fish in November, and data from these fish were excluded from any temporal analyses. Adult river lamprey Lampetra ayresis were also captured by the surface trawl, and their parasitic lifestyle suggests that they are potential transmission vectors for pathogens. A total of 33 river lamprey was collected for examination for the presence of Renibacterium salmoninarum.

Tissue collection and determination of infection. Salmon necropsies were conducted at the time of collection, and excised kidney tissue was stored on ice until slide preparation. River lamprey were stored at $-20^{\circ} \mathrm{C}$ until necropsy. Slides of kidney tissue and gut contents were prepared by the quantitative fluorescent antibody technique (qFAT) (Cvitanich 1994). The slide was stained with fluorescein isothiocyanate-conjugated polyclonal goat anti-Renibacterium salmoninarum antibody (Kirkegaard and Perry), and a total of 400 fields per slide were examined at $1000 \times$ magnification (objective numerical aperture 1.30) on a Zeiss Axiophot epifluorescence microscope. When accurate counts could not be performed before significant quenching of the fluorescent signal, minimum estimates of 12000 cells were applied.

Chinook salmon origins. Chinook salmon origins were examined using hatchery marks, CWTs, and genetic data. Any fish with detectable hatchery markings or tags was identified as 'marked' (a surrogate for hatchery fish). Snouts from marked fish with CWTs were removed and stored in $70 \%$ ethanol for subsequent decoding. Origins of fish with CWTs were determined from the Regional Mark Information System (Regional Mark Processing Center; www.rmpc. org/). For each CWT fish, the natal bay (i.e. first marine bay encountered in seaward migration) was assigned as the source bay. Fish lacking detectable hatchery markings or tags were identified as 'unmarked'. Although the majority of unmarked fish were likely to be from natural spawn origin, an unknown proportion of hatchery fish were included due to incomplete marking of hatchery fish (Rice et al. 2011). Origins of unmarked fish were estimated using genetic assignment techniques (Manel et al. 2005). Fin tissues were stored in non-denatured ethanol for subsequent DNA isolation using Wizard genomic DNA extraction kits (Promega). Isolated genomic DNA was used in polymerase chain reactions (PCRs) to amplify 13 microsatellite loci that have been standardized among all major West Coast salmon genetics laboratories (Seeb et al. 2007). PCR products were separated electrophoretically on an Applied Biosystems (ABI) 3100 genetic analyzer. ABI GeneScan and
Genotyper software were used to estimate allele sizes and assign genotypes. The origins of individual fish were estimated by using a regional baseline of population data compiled from the Genetic Analysis of Pacific Salmonids (GAPS) database for Chinook salmon (Seeb et al. 2007, Rice et al. 2011) and the ONCOR software program (Kalinowski et al. 2007). ONCOR uses the likelihood model of Rannala \& Mountain (1997) to calculate the relative probability that each baseline population produced a given individual's genotype. Probabilities were summed among genetically similar populations to assign fish to one of fifteen genetic stock groups in southern British Columbia and northwestern Washington (Rice et al. 2011). Genetic stock groups previously identified in Puget Sound included South Sound Spring (adult return time), South Sound/Hood Canal Fall, Whidbey Basin, and Nooksack River.

Data analysis. Infection data for each fish included total number of bacterial cells per slide (infection intensity) and infection status (presence or absence of bacteria). For Chinook salmon infection intensity was normalized for fish size by the following formula: $\ln \left[(1+B) / L^{3}\right]$, where $B$ is the total number of bacterial cells per slide and $L$ is the fork length. For some analyses, geographic designations were assigned to broader aggregate designations to examine larger scale effects or to obtain adequate sample sizes. The 52 individual sampling sites were assigned to thirteen watersheds, 8 bays (including a category for 'non-system' sites located outside of defined bays), 4 basins, or 2 sampling areas (Fig. 1). Because Chinook salmon in the North area were collected 2 wk earlier than those collected in the South area, fork length was examined separately by region. Statistical analyses included analysis of variance for fork length and for infection intensity; Spearman's rank correlation for infection prevalence and infection intensity; and the $G$-statistic and logistic regression modeling for infection prevalence. The critical p-value was set at 0.10 , unless indicated otherwise. The data set used for logistic regression contained a case record for each Chinook salmon examined. Each record included intrinsic target species factors (length, hatchery marking), physical conditions for the tow (water temperature and salinity at the tow site, depth of tow), and biological community factors for the tow (presence and density or mass of species collected). Regression models were evaluated by Akaike's Information Criterion (AIC; Akaike 1973, Burnham \& Anderson 2002), and differences in AIC scores were calculated against the lowest score to determine the most informative models. The data used for correlations were aggregated by month and by basin, bay, or watershed. Aggregations comprising 5 or fewer fish were excluded from the correlations. 


\section{RESULTS}

\section{Infection prevalence}

Prevalence of infection varied significantly by month, with the lowest proportion in May and the highest in June (Fig. 2; $G=58.1$, df = 11, p $\leq 0.0001$ ). Monthly prevalence of infection was positively correlated with average Chinook salmon density across all 3 geographic scales (Spearman's rank correlation, $\mathrm{p} \leq$ 0.002; Fig. 3). Furthermore, significant positive correlations between the monthly prevalence of infection and average Chinook salmon density were found for both marked and unmarked fish for all 3 geographic scales (Table 1). The prevalence of infection between unmarked and marked fish (31.2 and 32.7\%, respectively) was not different for each of the monthly samplings or for the entire survey (Fig. 2; Pearson $\chi^{2}, \mathrm{p}>$ 0.517, $\mathrm{N}=1751$ ).

Prevalence of infection differed widely among the capture locations. Among the 13 watersheds, prevalence varied significantly from the overall prevalence of $31.8 \%(G=290.9$, df $=12, \mathrm{p}<0.0001)$, with the northernmost and southernmost watersheds exhibiting the highest values (data not shown). Prevalence by bay also varied significantly $(G=384.7, \mathrm{df}=7, \mathrm{p}<0.0001)$ with high prevalence in the northernmost (Bellingham Bay), southernmost (Nisqually Reach), and a centrally located bay (Elliott/ Shilshole Bay; Fig. 4). Conversely, Skagit Bay exhibited the lowest prevalence. Infection prevalence was significantly different among

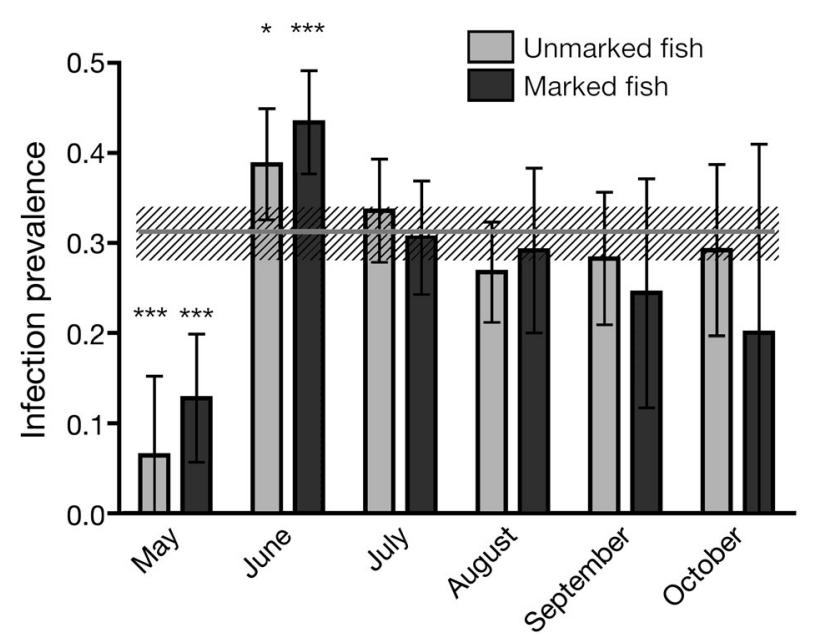

Fig. 2. Oncorhynchus tshawytscha. Infection prevalance $( \pm 95 \% \mathrm{CI})$ in marked and unmarked salmon across sampling months, with overall infection prevalence $( \pm 95 \%$ CI $)$ indicated by the horizontal line and hatched area. Values different from the overall prevalence of 0.318 are indicated by asterisks (G-tests; $\left.{ }^{*} \mathrm{p}<0.05,{ }^{* * *} \mathrm{p}<0.0001\right)$. Sample sizes (n) for each month: May, $\mathrm{n}=117$; June, $\mathrm{n}=528$; July, $\mathrm{n}=468$;

August, $\mathrm{n}=339$; September, $\mathrm{n}=190$; October, $\mathrm{n}=104$ all 4 basins $(G=185.3$, df $=3, \mathrm{p}<0.0001$; data not shown).

Among the logistic regression models for each geographic scale (basin, bay, watershed), the model by bay was most informative $(\Delta \mathrm{AIC}$ probability weight $=$ 0.941), and the likelihood of infection for fish captured in any bay was significantly higher than for fish captured in Skagit Bay (Table 2; $<$ 0.10). Fish captured in Bellingham Bay and Nisqually Reach had the highest odds of infection, while fish from Elliott/Shilshole Bay and Commencement Bays had intermediate odds of infection. Although fish captured in Possession Sound had the lowest odds of infection, the odds of infection were still significantly greater than for fish captured in Skagit Bay (Table 2).

Prevalence of infection did not appear to be associated with genetic origin or hatchery origin. Among unmarked fish, DNA microsatellite analysis of 417 fish resulted in assigning 297 fish to genetic stock groups with high confidence (probability $\geq 0.800$ ). Although infection prevalence among genetic stock groups was not uniform $(G, \mathrm{df}=4, \mathrm{p}=0.048)$, none were different from the overall prevalence. Four Puget Sound genetic stock groups (South Sound/Hood Canal Fall, South Sound Spring, Whidbey Basin, and Nooksack) and a combined group from the Fraser and Thompson Rivers in British Columbia had $\geq 4$ fish per capture bay. When these fish were examined by capture bay, prevalence was more similar among genetic stock groups within a capture bay than for a genetic stock group across the capture bays (Fig. 5). For example, the Whidbey Basin and South Sound/Hood Canal Fall stocks each exhibited low prevalence when captured in Skagit Bay (8.6 and $12.5 \%$, respectively). However, both of these stocks displayed elevated prevalence when captured in Bellingham Bay (38.9 and $75.0 \%$ ) or the Nisqually (50.0 and 57.1\%). Among the 270 coded wire tagged (CWT) fish, the prevalence by source bay ranged from $11.8 \%$ (Padilla Bay) to $53.5 \%$ (Bellingham Bay), with an overall prevalence of $31.1 \%$. When examined by capture bay, fish from different source bays that were collected within the same capture bay exhibited similar prevalence (Fig. 6). For example, fish originating from Skagit or Bellingham Bay displayed low infection prevalence when captured in Skagit Bay (10.5 and $14.3 \%$, respectively) but high prevalence when captured in Bellingham Bay (59.1 and 83.3\%, respectively).

Logistic regression identified significant risk factors exclusive of capture location. Four models containing physical, biological, and temporal factors were compared and the best overall model included 7 parameters (Table 3). For 6 of those parameters, the odds ratio was $>1$, indicating that the odds of infection increased as the parameter value increased. Only one parameter, 

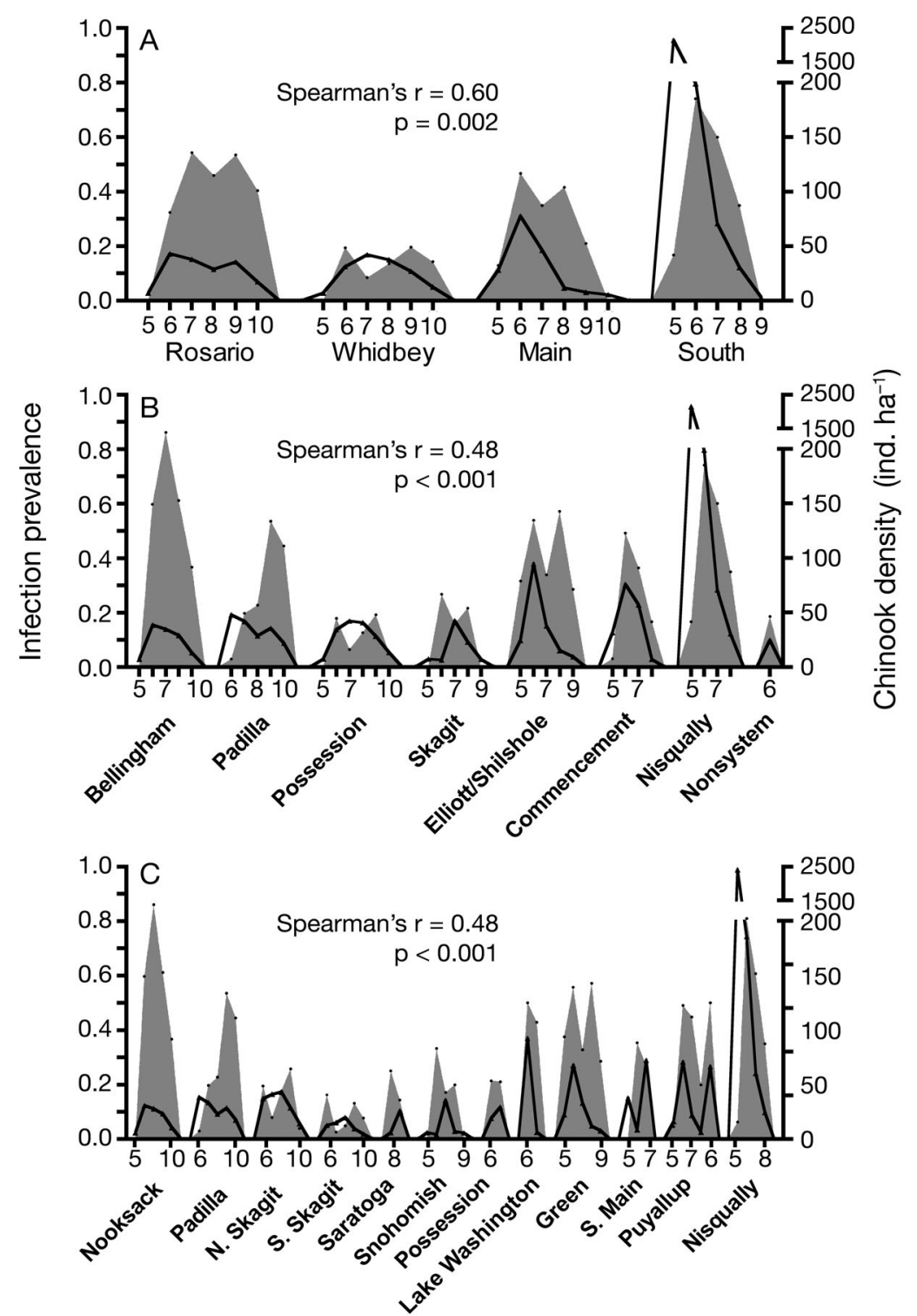

Fig. 3. Oncorhynchus tshawytscha. Comparison of monthly infection prevalence and average Chinook salmon density (no. per hectare) at 3 different geographic scales: (A) basin, (B) bay, and (C) watershed. Shaded plot: infection prevalence; line plot: Chinook salmon density. Geographic areas are ordered from north (left) to south (right). Numbers on the $x$-axis represent the month ( $5=$ May, $6=$ June, $7=$ July, $8=$ August, $9=$ September, $10=$ October). Spearman's correlation coefficient (Spearman's r) and associated p-value are included with each graph

density of unmarked Chinook salmon, had an odds ratio $<1$, indicating that the odds of infection decreased as that density increased. The p-values of the coefficients for these parameters were small, suggesting the effects were consistent among the sampled fish. However, the odds ratios were close to 1 indicating that the magnitude of the parameter effect was small.

This best overall regression model was examined by basin and by bay, and the significant odds ratios ( $p \leq$ 0.10) calculated (Table 4, Model 4). Water temperature and lamprey density were most frequently observed as significant positive factors (i.e. odds ratio $>1$ ) in several geographic areas, whereas forage fish density was a significant positive factor primarily in southern locations. Marked and unmarked Chinook salmon density effects varied depending upon the location and frequently had opposing values. For example, marked Chinook salmon density was a significant positive factor and unmarked Chinook salmon density was a significant negative factor (i.e. odds ratio $<1$ ) in southern locations (Table 4). Jellyfish mass was a positive factor only in the Rosario basin, and non-Chinook salmon density was not a significant factor at the basin or bay levels (Table 4).

Logistic regression linked the density of river lamprey with increased odds of infection, implicating this species as a vector for horizontal transmission of Renibacterium salmoninarum. If this is possible, the bacterium should be present in tissues of river lamprey. We employed qFAT to examine gut contents and kidney tissues from adult river lamprey collected in surface trawls from sites within Skagit Bay and Possession Sound. Bacteria were found in kidneys of $57.6 \%$ of the fish and in gut contents from $78.8 \%$ of fish $(n=33)$. The bacterial counts averaged 5.4 cells per slide for kidney (range 0 to 26) and 4.1 cells per slide for gut contents (range 0 to 15).

As expected, fork length varied by the month of collection (2-way ANOVA; North region: $F=111.49, \mathrm{df}=7, \mathrm{p}<$ 0.0001; South region: $F=92.02, \mathrm{df}=5$, $\mathrm{p}<0.0001$ ). In the North region, fork length was not affected by infection status $(F=0.33, \mathrm{df}=1, \mathrm{p}=0.563)$. However, in the South area, length was affected by infection status $(F=7.03$, df $=1, \mathrm{p}=$ $0.008)$, and there was an interaction between infection status and month $(F=4.13, \mathrm{df}=5$, $p=0.001$ ) that was due primarily to the large size difference in fish collected in September (Fig. 7).

\section{Infection intensity}

Temporal and geographic variations in infection intensity were significant. Fish collected in May exhibited higher infection intensity than all other months 
Table 1. Oncorhynchus tshawytscha. Spearman's rank correlation $\left(\mathrm{r}_{\mathrm{S}}\right)$ and associated $\mathrm{p}$-values for correlations between monthly infection prevalence and Chinook salmon density across 3 geographic scales. (The catch parameter, density of marked and unmarked Chinook salmon, was measured as mean no. of fish ha-1)

\begin{tabular}{|lcccr|}
\hline Scale & $\mathrm{N}$ & Catch parameter & $\mathrm{r}_{\mathrm{S}}$ & $\mathrm{p}$ \\
\hline Basin & 25 & Marked & 0.40 & 0.047 \\
& & Unmarked & 0.61 & 0.001 \\
Bay & \multirow{2}{*}{46} & Marked & 0.30 & 0.046 \\
& & Unmarked & 0.55 & $<0.001$ \\
Watershed & \multirow{2}{*}{70} & Marked & 0.41 & $<0.001$ \\
& & Unmarked & 0.45 & $<0.001$ \\
\end{tabular}

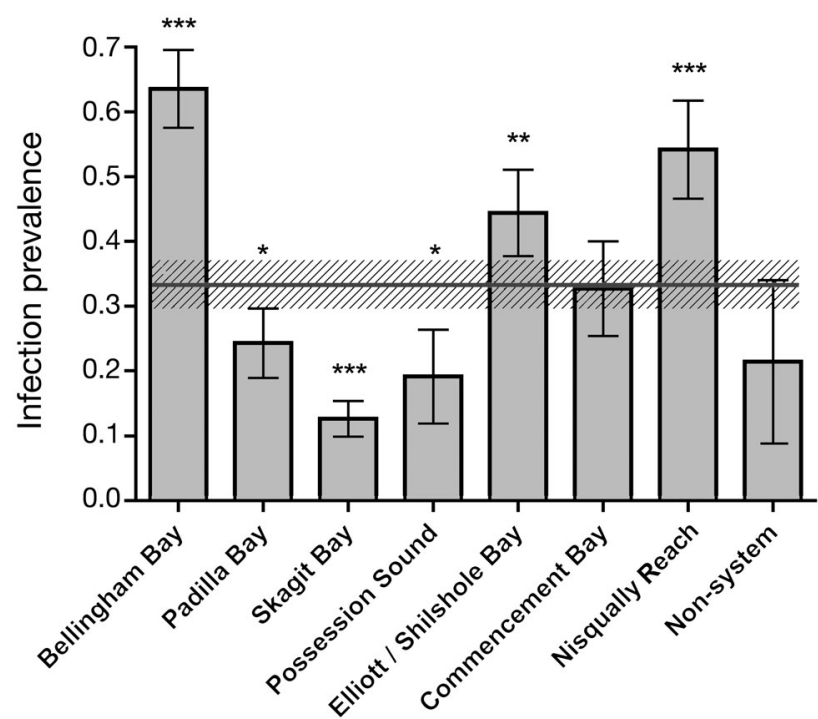

Fig. 4. Oncorhynchus tshawytscha. Infection prevalence $( \pm 95 \% \mathrm{CI})$ by capture bay; overall infection prevalence $( \pm 95 \% \mathrm{CI})$ indicated by horizontal line and hatched area. Values differing significantly from overall prevalence of 0.318 are indicated by asterisks (G-test, df $=7{ }^{*}{ }^{*} p<0.01,{ }^{* *} p<$ $\left.0.001,{ }^{* * *} \mathrm{p}<0.0001\right)$. Locations on $x$-axis are ordered from north (left) to south (right); non-system includes salmon not captured in a distinct geographic area

Table 2. Oncorhynchus tshawytscha. Odds ratios, p-values for the regression coefficient and the number of salmon by capture bay from the best logistic regression model of infection. Odds ratios are interpreted relative to salmon captured in Skagit Bay $(\mathrm{n}=560)$

\begin{tabular}{|lrrc|}
\hline Capture bay & Odds ratio & $\mathrm{p}$ & No. of fish \\
\hline Bellingham Bay & 12.015 & $<0.001$ & 247 \\
Padilla Bay & 2.210 & $<0.001$ & 247 \\
Possession Sound & 1.629 & 0.070 & 115 \\
Elliott/Shilshole Bay & 5.498 & $<0.001$ & 214 \\
Commencement Bay & 3.347 & $<0.001$ & 159 \\
Nisqually Reach & 8.140 & $<0.001$ & 168 \\
Non-system & 1.878 & 0.112 & 42 \\
\hline
\end{tabular}

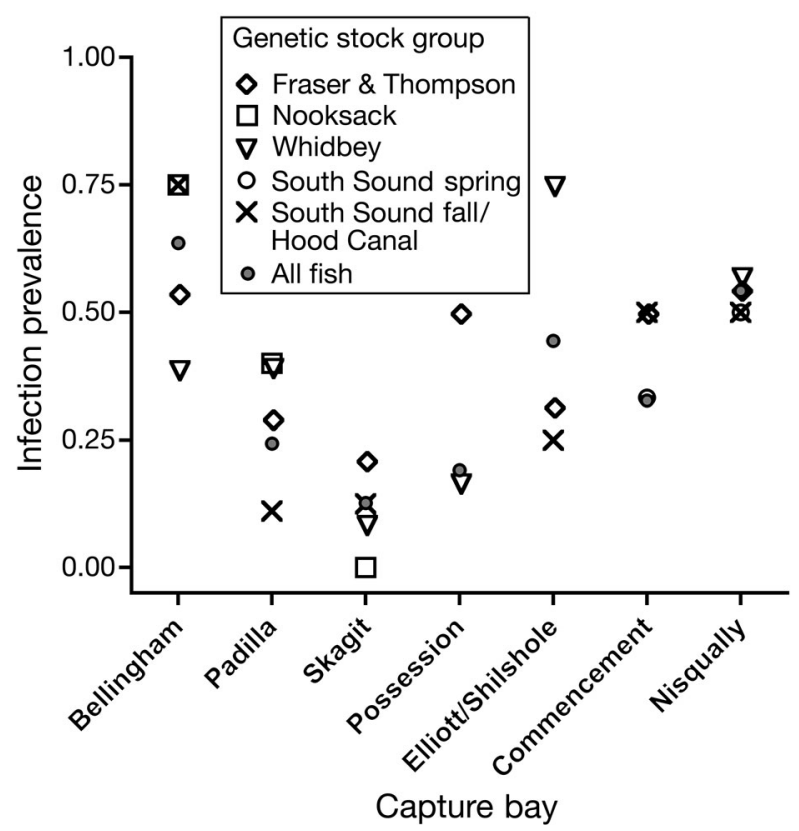

Fig. 5. Oncorhynchus tshawytscha. Infection prevalence among unmarked salmon by genetic stock group and capture bay. Results shown only for groups with 4 or more samples per stock group per capture bay

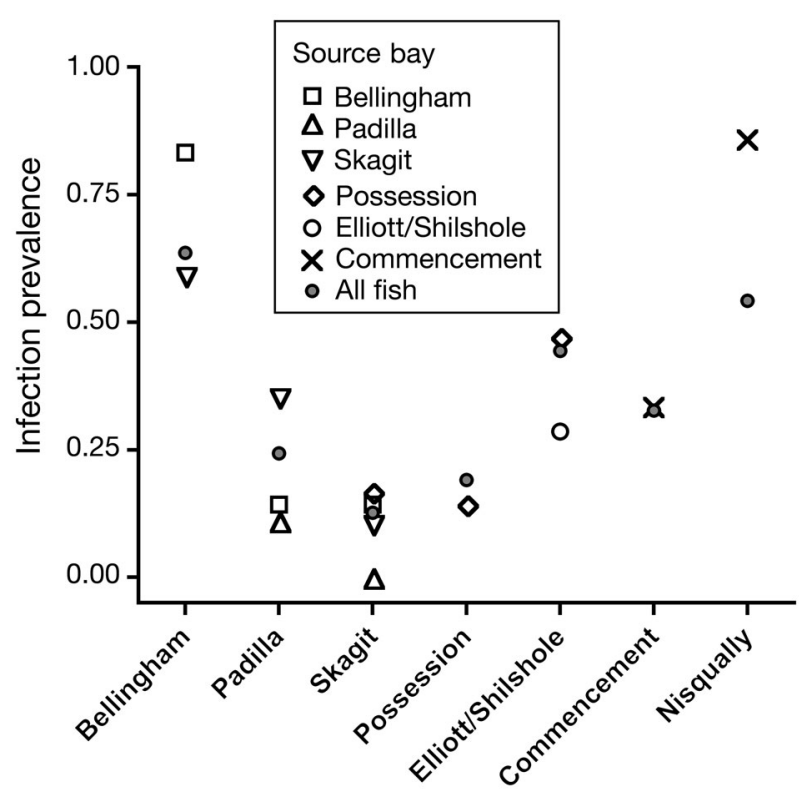

Capture bay

Fig. 6. Oncorhynchus tshawytscha. Infection prevalence among coded wire tagged salmon by source bay and capture bay. Results shown only for groups with 4 or more samples per data point

(ANOVA, $F=27.30, \mathrm{df}=5, \mathrm{p}<0.0001$; Scheffe post-hoc comparisons, $\mathrm{p} \leq 0.005)$. Correlations between infection intensity and sampling month for both marked and unmarked fish were negative (Spearman's rank corre- 
Table 3. Oncorhynchus tshawytscha. Comparison of best logistic regression models of infection showing Akaike's Information Criterion (AIC) values, differences in AIC values $\left(\Delta_{\mathrm{i}}\right)$, AIC weights, odds ratios, and p-values of the coefficient for parameters of water temperature (Temp), salinity, depth, density of marked Chinook salmon (DensCS $\mathrm{C}_{\mathrm{mark}}$ ), density of unmarked Chinook salmon (DensCS $S_{\text {no mark }}$ ), density of salmon other than Chinook salmon (Dens NonCS), jellyfish biomass (Jellyfish), density of river lamprey (DensLamp), density of forage fish (DensForage), and sampling month (Month). Only parameters with $\mathrm{p} \leq 0.10$ were included in the model

\begin{tabular}{|c|c|c|c|c|c|c|}
\hline \multicolumn{2}{|c|}{ Model AIC } & \multirow{2}{*}{$\begin{array}{c}\Delta_{\mathrm{i}} \\
5.3\end{array}$} & \multirow{2}{*}{$\begin{array}{c}\begin{array}{c}\text { AIC } \\
\text { weight }\end{array} \\
0.042\end{array}$} & $\begin{array}{l}\text { Parameter } \\
\text { Temp }\end{array}$ & $\begin{array}{c}\begin{array}{c}\text { Odds } \\
\text { ratio }\end{array} \\
1.224\end{array}$ & $\begin{array}{c}\mathrm{p} \\
<0.001\end{array}$ \\
\hline 1 & 2119.812 & & & $\begin{array}{l}\text { Temp } \\
\text { Salinity } \\
\text { Depth } \\
\text { DensCS }_{\text {mark }} \\
\text { DensCS }_{\text {no mark }} \\
\text { Dens NonCS } \\
\text { Jellyfish } \\
\text { DensLamp } \\
\text { DensForage } \\
\text { Month }\end{array}$ & $\begin{array}{l}1.224 \\
0.992 \\
1.005 \\
1.003 \\
0.992 \\
1.000 \\
1.006 \\
1.008 \\
1.000 \\
1.010\end{array}$ & $\begin{array}{r}<0.001 \\
0.471 \\
0.538 \\
0.004 \\
0.003 \\
0.001 \\
0.014 \\
0.084 \\
0.074 \\
0.843\end{array}$ \\
\hline 2 & 2117.8514 & 3.3 & 0.113 & $\begin{array}{l}\text { Temp } \\
\text { Salinity } \\
\text { Depth } \\
\text { DensCS }_{\text {mark }} \\
\text { DensCS }_{\text {no mark }} \\
\text { Dens NonCS } \\
\text { Jellyfish } \\
\text { DensLamp } \\
\text { DensForage }\end{array}$ & $\begin{array}{l}1.224 \\
0.992 \\
1.005 \\
1.003 \\
0.992 \\
1.000 \\
1.006 \\
1.008 \\
1.000\end{array}$ & $\begin{array}{r}<0.001 \\
0.488 \\
0.542 \\
0.002 \\
0.002 \\
<0.001 \\
0.014 \\
0.085 \\
0.067\end{array}$ \\
\hline 3 & 2116.2212 & 1.7 & 0.255 & $\begin{array}{l}\text { Temp } \\
\text { Salinity } \\
\text { DensCS }_{\text {mark }} \\
\text { DensCS } \\
\text { no mark } \\
\text { Dens NonCS } \\
\text { Jellyfish } \\
\text { DensLamp } \\
\text { DensForage }\end{array}$ & $\begin{array}{l}1.227 \\
0.994 \\
1.003 \\
0.992 \\
1.000 \\
1.007 \\
1.008 \\
1.000\end{array}$ & $\begin{array}{r}<0.001 \\
0.567 \\
0.002 \\
0.002 \\
<0.001 \\
0.006 \\
0.090 \\
0.076\end{array}$ \\
\hline 4 & 2114.5458 & 0.0 & 0.590 & $\begin{array}{l}\text { Temp } \\
\text { DensCS }_{\text {mark }} \\
\text { DensCS } \\
\text { no mark } \\
\text { Dens NonCS } \\
\text { Jellyfish } \\
\text { DensLamp } \\
\text { DensForage }\end{array}$ & $\begin{array}{l}1.233 \\
1.003 \\
0.992 \\
1.000 \\
1.007 \\
1.008 \\
1.000\end{array}$ & $\begin{array}{r}<0.001 \\
0.002 \\
0.002 \\
<0.001 \\
0.002 \\
0.057 \\
0.076\end{array}$ \\
\hline
\end{tabular}

lation $=-0.943, \mathrm{p} \leq 0.005)$. Geographic differences in size-normalized infection intensity were best observed at the capture bay level (ANOVA, $F=10.21$, df $=7, \mathrm{p}<$ 0.0001), with higher intensities for fish collected in Bellingham and Nisqually Bays, lower intensities for fish collected in Padilla and Skagit Bays, and intermediate for other locations (Fig. 8) However, none of the infected fish exhibited clinical evidence of BKD, such as kidney granulomas or ascites. For $77 \%$ of the infected fish, bacterial cell counts were $\leq 10$ cells. For $5.6 \%$ of infected fish (31 of 557), bacterial cell counts were $\geq 100$ cells and 4 of these 31 had $>1000$ cells.
Consistent positive correlations were observed between infection intensity and Chinook salmon catch parameters (Table 5). Across all 3 geographic scales (basin, bay, watershed), the infection intensity was positively correlated with total Chinook salmon density, with the density of marked Chinook salmon, and with the percentage of marked Chinook salmon in the tow. The correlation coefficient for the marked Chinook salmon density was consistently the highest for all comparisons. In contrast, there were no significant correlations with the density of unmarked Chinook salmon (Table 5). Furthermore, infection intensity was not different between all marked and all unmarked fish ( $t$-test, 2-tailed test, $\mathrm{p}=0.8422$ ).

\section{DISCUSSION}

Disease surveillance is not typically included in ecological field assessments because many diseases are episodic and opportunities to detect pathogens can be relatively transient. Habitat overlap between infected pathogen reservoirs and susceptible populations of endangered species can exacerbate the risk of extinction without observing or understanding the hazard. Multidisciplinary monitoring can provide beneficial insights into environmental factors that are associated with the presence of pathogens, and in some instances, disease profiling can be used as an indicator for environmental status (Myers et al. 2008, Stentiford et al. 2009).

The current study examined both biotic and abiotic factors associated with a bacterial infection in recently emigrant juvenile Chinook salmon. Among these factors, Chinook salmon density emerged as important for infection. Chinook salmon density correlated with infection prevalence (Fig. 3) and intensity of infection (Table 5) across spatial and temporal scales, suggesting that the association is not a population-specific or a local effect. The association of Chinook salmon density with infection is consistent with a horizontal transmission scenario among juvenile fish. Sympatry between infected and susceptible fish provides the opportunity for pathogen transmission, and increased host density elevates the probability of transmission. For bacterial kidney disease, infected fish shed bacteria in water (Austin \& Rayment 1985, McKibben \& Pascho 1999), and cohabitation of infected and naïve fish is an effective method of experimental challenge (Murray et al. 1992, Alcorn et al. 2005).

The release of hatchery Chinook salmon is likely to have an impact on infection for several reasons. First, infection intensity correlated with the percentage of marked Chinook salmon and the marked Chinook salmon density, but not unmarked Chinook salmon density (Table 5). Second, marked Chinook salmon 
Table 4. Oncorhynchus tshawytscha. Odds ratios for significant parameters $(\mathrm{p} \leq$ 0.10 ) from logistic regressions by basin or by bay. Non-Chinook salmon density was included in the analysis but was not a significant parameter for any basin or bay. -: parameter was not significant; ${ }^{*}$ : not evaluated because no lamprey were captured

\begin{tabular}{|c|c|c|c|c|c|c|}
\hline & Temp & $\begin{array}{l}\text { Chinoo } \\
\text { Marked }\end{array}$ & $\begin{array}{l}\text { density } \\
\text { Jnmarked }\end{array}$ & $\begin{array}{l}\text { Lamprey } \\
\text { density }\end{array}$ & $\begin{array}{l}\text { Jellyfish } \\
\text { mass }\end{array}$ & $\begin{array}{l}\text { Forage } \\
\text { fish } \\
\text { density }\end{array}$ \\
\hline \multicolumn{7}{|l|}{ Basins } \\
\hline Rosario & 1.2587 & 0.9335 & 1.0228 & 1.0293 & 1.0158 & - \\
\hline Whidbey & - & - & - & - & - & - \\
\hline Main & - & - & 1.0164 & - & - & - \\
\hline South & 1.5778 & 1.0103 & 0.9727 & $*$ & - & 1.0047 \\
\hline \multicolumn{7}{|l|}{ Bays } \\
\hline Bellingham & 1.3107 & - & - & 1.0256 & - & - \\
\hline Padilla & - & 0.9508 & 1.0342 & - & - & - \\
\hline Skagit & - & - & - & 1.0105 & - & - \\
\hline Possession & - & - & - & - & - & - \\
\hline Elliott/Shilshole & - & - & - & 1.9749 & - & - \\
\hline Commencement & 1.5053 & 0.9802 & 1.0530 & $*$ & - & 1.0480 \\
\hline Nisqually & 1.1578 & 1.0103 & 0.9727 & * & 1.0047 & - \\
\hline
\end{tabular}

Prevalence of infection varied greatly among the capture bays, and capture bay had the greatest effect on infection. The lowest prevalence was observed among fish collected in Skagit Bay (Fig. 4), which receives the largest number and greatest proportion of wild juvenile Chinook salmon of all the bays that we examined (Rice et al. 2011). The odds of infection among fish collected in Bellingham Bay, Elliott/ Shilshole Bay, Commencement Bay, and Nisqually Reach was 3 to 12 times higher than that for fish collected in Skagit Bay (Table 2). Three of these bays are predominantly urban and industrial in character, while the Skagit Bay receives inputs primarily from rural and agricultural areas. However, there are no major urban or industrial activities adjacent to Nisqually Reach (overall infection prevalence $=54.2 \%$ ), demonstrating that there is no clear relationship between infection prevalence and upland development and use. The effect of the capture location may reside in factors that were not measured in our study, such as a pathogen reservoir in a non-Chinook salmon host.

One possible source of infection variation could be fish from a particular hatchery origin or genetic stock. We examined fish origins using 3 different approaches (hatchery mark, hatchery origin, genetic stock). One caveat about hatchery markings is that some Puget Sound hatcheries mark otoliths, but do not clip fins or use coded wire tags. Therefore, some fish classified as unmarked may actually be hatchery fish, so our comparisons are likely between known hatchery fish and fish that are a mixture of hatchery and naturally produced individuals. We did not observe a significant difference in infection prevalence between marked and unmarked fish (Fig. 2). This observation suggests homogeneity of infection between the 2 groups and is consistent with pathogen transmission during early marine emigration. Coded wire tags in some marked individuals provided a subset of hatchery samples with known freshwater release locations, and we did not observe an obvious 'hotspot' hatchery source of infection in our data (Fig. 6).

We used genetic data to estimate the genetic stock of origin of a subset of unmarked fish. While differential susceptibilities to BKD have been observed among populations of salmon (McGeer et al. 1991, Beacham \& Evelyn 1992), significant BKD resistance associated with locus zygosity (overdominance) has been limited to the major histocompatibility class IIB locus (Turner et al. 2007), and specific genetic components underpathogen transmission. 

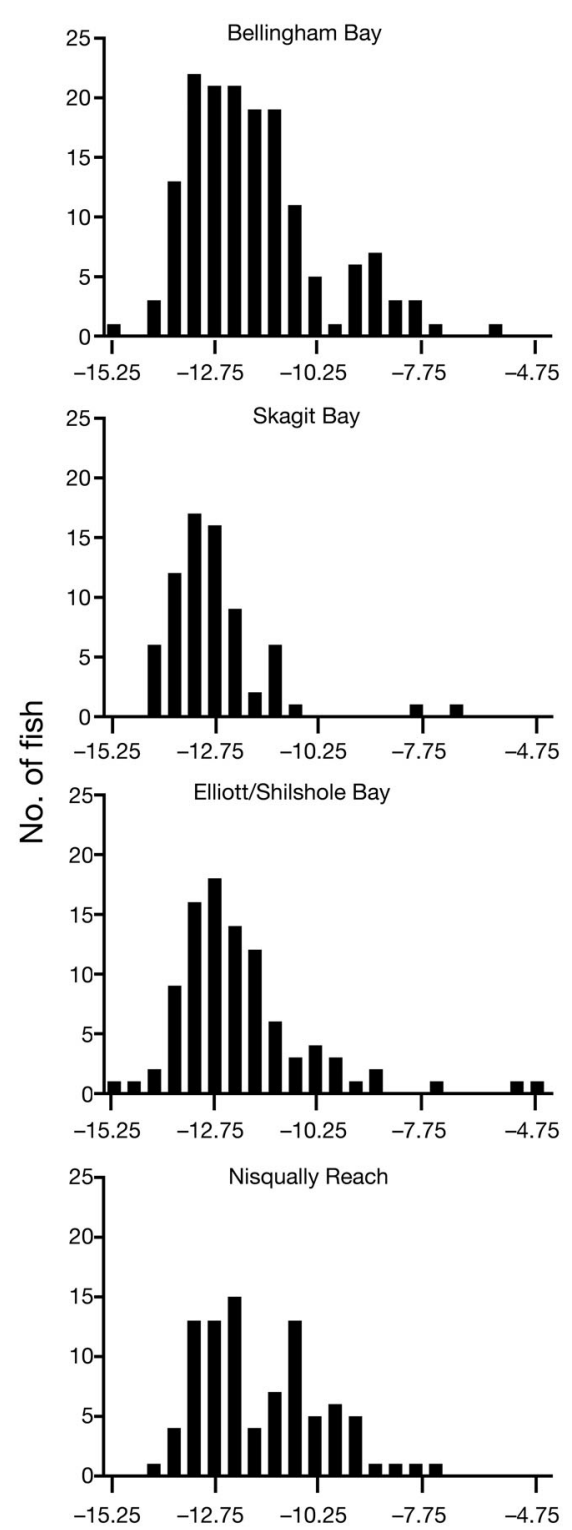

Normalized infection intensity
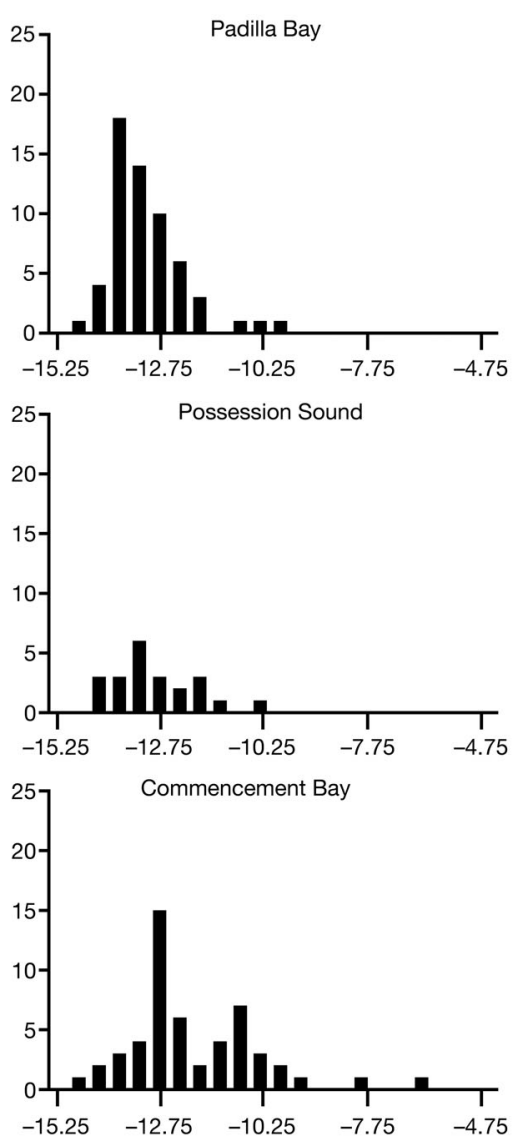

Normalized infection intensity

Fig. 8. Oncorhynchus tshawytscha. Size-normalized infection intensities for infected salmon $(n=557)$ by capture bay
Although a geographic risk factor may integrate features that are characteristic for that location, physical factors for each tow site were included in the regression analysis to determine their significance. Temperature emerged as a positive factor for prevalence, while salinity and depth of tow were not important (Tables 3 \& 4). Temperature can modulate both pathogen and host physiology, and the in vitro optimal growth temperature range for Renibacterium salmoninarum is 15 to $18^{\circ} \mathrm{C}$. Fish experimentally infected with $R$. salmoninarum succumbed more rapidly at temperatures between 15 and $20.5^{\circ} \mathrm{C}$ (Sanders et al. 1978), a range overlapping approximately half of our temperature observations. Immune responses in poikilothermic fish tend to increase with temperature, but they are not simply linear (Le Morvan et al. 1998, Watts et al. 2001, Pettersen et al. 2005), while certain innate immune responses in salmon, such as serum lysozyme and serum complement activities, are not affected by water temperature (Alcorn et al. 2002). The temperature relationship detected in this study is consistent with observations of disease exacerbation at higher temperatures (reviewed in Richter \& Kolmes 2005), and suggests that scenarios of increasing water temperatures could result in greater infection prevalence.

The emergence of river lamprey density as a positive risk factor was unanticipated, and the majority of adult river lamprey we examined had Renibacterium salmoninarum in both the gut contents and kidney tissue. $R$. salmoninarum has been isolated from sea lam-

lying resistance to BKD in Chinook salmon have not been identified (Beacham \& Evelyn 1992, Johnson et al. 2003, Hard et al. 2006). As expected, the genetic data did not provide as fine a geographic resolution for freshwater origin as the CWT data. For example, in the genetic analysis we grouped fall run populations from throughout southern Puget Sound and Hood Canal because they are genetically very similar, which likely reflects extensive transfers of hatchery stocks in the area (Myers et al. 1998). Nonetheless, we did not find evidence that genetic stock was an important influence on infection, and our data indicate that the capture location was much more strongly associated with infection than was genetic stock (Fig. 5). prey Petromyzon marinus from the Great Lakes (Eissa et al. 2006) where epizootics of BKD have occurred among Chinook salmon (Holey et al. 1998), and we have observed $R$. salmoninarum in kidney tissue from adult Pacific lamprey Lampetra tridentata (Gairdner) from the Columbia River (L. Rhodes unpubl. obs.). During the marine adult phase, river lamprey parasitize schooling fish such as salmon and herring by feeding on epidermis, muscle, and blood (Beamish 1980, Beamish \& Youson 1987). The presence of bacteria in lamprey kidney tissue indicates that these fish can become infected, in contrast to attempts to experimentally infect Pacific lamprey (Bell \& Traxler 1986). The majority of lamprey catches occurred primarily in 
Table 5. Oncorhynchus tshawytscha. Spearman's rank correlation $\left(\mathrm{r}_{\mathrm{S}}\right)$ between monthly size-normalized infection intensity and monthly Chinook salmon catch information for marked Chinook salmon density (DensCS $\mathrm{S}_{\text {mark }}$ ), unmarked Chi-

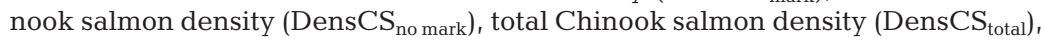
and percentage of Chinook salmon that are marked (PctCS ${ }_{\text {mark }}$ ) across 3 geographic scales. ${ }^{*} \mathrm{p}<0.05$; Chinook density was measured as mean no. of fish ha ${ }^{-1}$

\begin{tabular}{|c|c|c|c|c|}
\hline Scale & $\mathrm{N}$ & $\begin{array}{l}\text { Catch } \\
\text { parameter }\end{array}$ & $\begin{array}{c}\text { Mean intensity } \\
\mathrm{r}_{\mathrm{S}}\end{array}$ & $\begin{array}{c}\text { Median intensity } \\
\mathrm{r}_{\mathrm{S}}\end{array}$ \\
\hline Basin & 25 & $\begin{array}{l}\text { DensCS } \\
\text { Denark } \\
\text { DeS }_{\text {no mark }} \\
\text { DensCS }_{\text {total }} \\
\text { PctCS }_{\text {mark }}\end{array}$ & $\begin{array}{c}0.745^{*} \\
0.335 \\
0.666^{*} \\
0.603^{*}\end{array}$ & $\begin{array}{c}0.668^{*} \\
0.318 \\
0.644^{*} \\
0.554^{*}\end{array}$ \\
\hline Bay & 46 & $\begin{array}{l}\text { DensCS } \\
\text { Densark } \\
\text { DeS }_{\text {no mark }} \\
\text { DensCS }_{\text {total }} \\
\text { PctCS } \\
\text { mark }\end{array}$ & $\begin{array}{c}0.623^{*} \\
0.328 \\
0.564^{*} \\
0.360^{*}\end{array}$ & $\begin{array}{c}0.605^{*} \\
0.301 \\
0.544^{*} \\
0.362^{*}\end{array}$ \\
\hline Watershed & 70 & $\begin{array}{l}\text { DensCS } \\
\text { Denark } \\
\text { Dens }_{\text {no mark }} \\
\text { DensC }_{\text {total }} \\
\text { PctCS }_{\text {mark }}\end{array}$ & $\begin{array}{c}0.578^{*} \\
0.116 \\
0.362^{*} \\
0.497^{*}\end{array}$ & $\begin{array}{c}0.507^{*} \\
0.088 \\
0.302^{*} \\
0.417^{*}\end{array}$ \\
\hline
\end{tabular}

ment, and these fish are likely to be energetically disadvantaged. Because the intensity of infection was low for the majority of fish we examined, it is possible that the heavily infected fish did not successfully emigrate to marine waters.

The individual metric of fork length was the same between uninfected and infected fish for each month of the study, an observation that is consistent with susceptibility to infection throughout the juvenile life stage. The inverse relationship between infection intensity and fork length may be a result of dilution by growth of the host, especially for a slowly replicating bacterial species such as Renibacterium salmoninarum. Furthermore, immune responses in salmonids such as serum IgM levels rise during the postsmoltification period (Melingen et al. $1995 \mathrm{a}, \mathrm{b})$, possibly resulting in better

the North part of the study area, with $70 \%$ of the lamprey captured in Skagit Bay, which had the lowest prevalence of infection. Thus, the presence of lampreys alone is insufficient for high infection prevalence, and supports the possibility that lamprey serve as vectors, rather than reservoirs, of $R$. salmoninarum for juvenile salmon.

Several factors that were significant in the overall logistic regression failed to exhibit widespread significance at the basin or bay level. The density of forage fish and jellyfish mass were significant factors in only 1 or 2 geographic locations, and the density of nonChinook salmon was not significant in any basin or bay (Table 4). These factors may have very weak effects, and indeed the odds ratios for some of them were very close to one. Alternatively, they may be surrogates for community features that were not captured by the tow data, e.g. altered community structures (Lynam et al. 2006).

Downstream migration and smoltification could exert a selective pressure against more heavily infected or clinically ill fish. Juvenile salmon with BKD exhibit reduced survival when exposed to stressors simulating migration (Sanders et al. 1992, Moles 1997) and while transitioning through smoltification (Mesa et al. 1999). Clinically affected fish are also more susceptible to predation (Mesa et al. 1998). Juvenile Chinook salmon with moderate to severe infection of Renibacterium salmoninarum have persistently lowered hematocrit, lowered plasma glucose, and elevated plasma lactate (Mesa et al. 2000). The altered parameters are indicative of reduced capacity for sustained move- infection control in larger fish.

This study underscores the value of using a multidisciplinary approach for disease studies and for including disease assessments in ecological studies. Incorporation of both environmental and catch data with biological information for each fish allowed identification of risk factors associated with an increased odds of infection. The effect of Chinook salmon density at multiple spatial scales, effect of capture bay, the negligible effect of genetic stock and hatchery origin, and the low infection intensity among most of the affected fish are features consistent with horizontal transmission of Renibacterium salmoninarum occurring during the neritic period and with recently acquired infections. A role for adult river lamprey (as vectors or reservoirs) in pathogen transmission was implicated, and the source of infection could be juvenile Chinook salmon, other salmonids, marine fish (Kent et al. 1998), or even invertebrates serving as passive reservoirs of $R$. salmoninarum (Starliper \& Morrison 2000). If horizontal transmission among juvenile Chinook salmon occurs during the first few months after emigration into seawater, there is potential for pathogen interaction between sympatric wild and hatchery stocks. Ideally, prerelease hatchery fish would be managed for the lowest achievable level of infection, including routine monitoring for pathogens before release. Including health status criteria in the hatchery release decision would provide long-term benefits such as improved survival to adulthood for both the fish belonging to the managed stock and for the wild stocks they encounter during their lifetime. 
Acknowledgements. We thank the Environmental Conservation Division (Northwest Fisheries Science Center, NOAA Fisheries, Seattle) for research vessel and field staff support. F. Sommers was instrumental in ensuring appropriate sample collection. D. Kuligowski collected the genetic data used in the study. E. Smith analyzed the river lamprey samples. Funding support was from Northwest Fisheries Science Center's Internal Grants Program, Seattle City Light, and the US Army Corps of Engineers.

\section{LITERATURE CITED}

Akaike H (1973) Information theory and an extension of the maximum likelihood principle. In: Petrov BN, Csaki F (eds) Proceedings of the Second International Symposium on Information Theory. Akademiai Kiado, Budapest, p $267-281$

Alcorn SW, Murray AL, Pascho RJ (2002) Effects of rearing temperature on immune functions in sockeye salmon (Oncorhynchus nerka). Fish Shellfish Immunol 12: 303-334

> Alcorn S, Murray AL, Pascho RJ, Varney J (2005) A cohabitation challenge to compare the efficacies of vaccines for bacterial kidney disease (BKD) in chinook salmon Oncorhynchus tshawytscha. Dis Aquat Org 63:151-160

Anderson RM, May RM (1978) Regulation and stability of host-parasite population interactions. I. Regulatory processes. J Anim Ecol 47:219-247

> Arkoosh MR, Clemons E, Kagley AN, Stafford C and others (2004) Survey of pathogens in juvenile salmon Oncorhynchus spp. migrating through Pacific Northwest estuaries. J Aquat Anim Health 16:186-196

Austin B, Rayment JN (1985) Epizootiology of Renibacterium salmoninarum, the causal agent of bacterial kidney disease in salmonid fish. J Fish Dis 8:505-509

Balfry SK, Albright LJ, Evelyn TPT (1996) Horizontal transfer of Renibacterium salmoninarum among farmed salmonids via the fecal-oral route. Dis Aquat Org 25:63-69

Beacham TD, Evelyn TPT (1992) Population and genetic variation in resistance of Chinook salmon to vibriosis, furunculosis, and bacterial kidney disease. J Aquat Anim Health 4:153-167

Beamish RJ (1980) Adult biology of the river lamprey (Lampetra ayresi) and the Pacific lamprey (Lampetra tridentata) from the Pacific coast of Canada. Can J Fish Aquat Sci 37: 1906-1923

- Beamish RJ, Youson JH (1987) Life history and abundance of young adult Lampetra ayresi in the Fraser River and their possible impact on salmon and herring stocks in the Strait of Georgia. Can J Fish Aquat Sci 44:525-537

Bell GR, Traxler GS (1986) Resistance of the Pacific lamprey, Lampetra tridentata (Gairdner), to challenge by Renibacterium salmoninarum, the causative agent of kidney disease in salmonids. J Fish Dis 9:277-279

Bruno DW (2004) Prevalence and diagnosis of bacterial kidney disease (BKD) in Scotland between 1990 and 2002. Dis Aquat Org 59:125-130

Burnham KP, Anderson DR (2002) Model selection and multimodel inference: a practical information-theoretic approach. Springer-Verlag, New York, NY

> Clifford DL, Mazet JAK, Dubovi EJ, Garcelon DK, Coonan TJ, Conrad PA, Munson L (2006) Pathogen exposure in endangered island fox (Urocyon littoralis) populations: implications for conservation management. Biol Conserv 131:230-243

Cvitanich JD (1994) Improvements in the direct fluorescent antibody technique for the detection, identification, and quantification of Renibacterium salmoninarum in salmonid kidney smears. J Aquat Anim Health 6:1-12

- Daszak P, Cunningham AA, Hyatt AD (2000) Emerging infectious diseases of wildlife - threats to biodiversity and human health. Science 287:443-449

> Eissa AE, Elsayed EE, McDonald R, Faisal M (2006) First record of Renibacterium salmoninarum in the sea lamprey (Petromyzon marinus). J Wildl Dis 42:556-560

Elliott DG, Pascho RJ (2001) Evidence that coded-wiretagging procedures can enhance transmission of Renibacterium salmoninarum in Chinook salmon. J Aquat Anim Health 13:181-193

Evelyn TPT, Ketcheson JE, Prosperi-Porta L (1986a) Use of erythromycin as a means of preventing vertical transmission of Renibacterium salmoninarum. Dis Aquat Org 2:7-11

Evelyn TPT, Prosperi-Porta L, Ketcheson JE (1986b) Experimental intra-ovum infection of salmonid eggs with Renibacterium salmoninarum and vertical transmission of the pathogen with such eggs despite their treatment with erythromycin. Dis Aquat Org 1:197-202

- Good TP, Beechie TJ, McElhany P, McClure MM, Ruckelshaus MH (2007) Recovery planning for Endangered Species Act-listed Pacific salmon: using science to inform goals and strategies. Fisheries 32:426-440

Hard JJ, Elliott DG, Pascho RJ, Chase DM, Park LK, Winton JR, Campton DE (2006) Genetic effects of ELISA-based segregation for control of bacterial kidney disease in Chinook salmon (Oncorhynchus tshawytscha). Can J Fish Aquat Sci 63:2793-2808

Haydon DT, Cleaveland S, Taylor LH, Laurenson MK (2002) Identifying reservoirs of infection: a conceptual and practical challenge. Emerg Infect Dis 8:1468-1473

Holey ME, Elliott RF, Marcquenski SV, Hnath JG, Smith KD (1998) Chinook salmon epizootics in Lake Michigan: Possible contributing factors and management implications. J Aquat Anim Health 10:202-210

Johnson RM, Bryden CA, Heath DD (2003) Utility of genetically based health indicators for selection purposes in captive-reared Chinook salmon, Oncorhynchus tshawytscha, Walbaum. Aquacult Res 34:1029-1036

Johnson PTJ, Ives AR, Lathrop RC, Carpenter SR (2009) Longterm disease dynamics in lakes: causes and consequences of chytrid infections in Daphnia populations. Ecology 90:132-144

Kalinowski ST, Manlove KR, Taper ML (2007) ONCOR: a computer program for genetic stock identification. Department of Ecology, Montana State University, Bozeman, MT

Kent ML, Traxler GS, Kieser D, Richard J and others (1998) Survey of salmonid pathogens in ocean-caught fishes in British Columbia, Canada. J Aquat Anim Health 10: 211-219

Le Morvan C, Troutaud D, Deschaux P (1998) Differential effects of temperature on specific and nonspecific immune defences in fish. J Exp Biol 201:165-168

Lynam CP, Gibbons MJ, Axelsen BE, Sparks CA, Coetzee J, Heywood BG, Brierley AS (2006) Jellyfish overtake fish in a heavily fished ecosystem. Curr Biol 16:R492-R493

Manel S, Gaggiotti OE, Waples RS (2005) Assignment methods: matching biological questions with appropriate techniques. Trends Ecol Evol 20:136-142

McGeer JC, Baranyi L, Iwama GK (1991) Physiological responses to challenge tests in six stocks of coho salmon (Oncorhynchus kisutch). Can J Fish Aquat Sci 48: 1761-1771

- McKibben CL, Pascho RJ (1999) Shedding of Renibacterium salmoninarum by infected Chinook salmon Oncorhynchus 
tschawytscha. Dis Aquat Org 38:75-79

McVicar AH, Olivier G, Traxler GS, Jones S, Kieser D, MacKinnon AM (2006) Cultured and wild fish disease interactions in the Canadian marine environment. In: A scientific review of the potential environmental effects of aquaculture in aquatic ecosystems, Vol 4. Can Tech Rep Fish Aquat Sci 2450

Melingen GO, Nilsen F, Wergeland HI (1995a) The serum antibody levels in Atlantic salmon (Salmo salar L.) after vaccination with Vibrio salmonicida at different times during the smolting and early post-smolt period. Fish Shellfish Immunol 5:223-235

Melingen GO, Stefansson SO, Berg A, Wergeland HI (1995b) Changes in serum protein and IgM concentration during smolting and early post-smolt period in vaccinated and unvaccinated Atlantic salmon (Salmo salar L.). Fish Shellfish Immunol 5:211-221

Mesa MG, Poe TP, Maule AG, Schreck CB (1998) Vulnerability to predation and physiological stress responses in juvenile chinook salmon (Oncorhynchus tshawytscha) experimentally infected with Renibacterium salmoninarum. Can J Fish Aquat Sci 55:1599-1606

Mesa MG, Maule AG, Poe TP, Schreck CB (1999) Influence of bacterial kidney disease on smoltification in salmonids: Is it a case of double jeopardy? Aquaculture 174:25-41

Mesa MG, Maule AG, Schreck CB (2000) Interaction of infection with Renibacterium salmoninarum and physical stress in juvenile chinook salmon: physiological responses, disease progression, and mortality. Trans Am Fish Soc 129: 158-173

Meyers TR, Thrower F, Short S, Lipson K, Joyce J, Farrington C, Doherty S (1999) Different prevalences of Renibacterium salmoninarum detected by ELISA in Alaskan chinook salmon Oncorhynchus tshawytscha spawned from freshwater and seawater. Dis Aquat Org 35:101-105

Mobrand LE, Barr J, Blankenship L, Campton DE and others (2005) Hatchery reform in Washington state: principles and emerging issues. Fisheries 30:11-23

> Moles A (1997) Effect of bacterial kidney disease on saltwater adaptation of coho salmon smolts. J Aquat Anim Health 9:230-233

Montali RJ, Mikota SK, Cheng LI (2001) Mycobacterium tuberculosis in zoo and wildlife species. Rev Sci Tech 20: 291-303

Mumby PJ, Hedley JD, Zychaluk K, Harborne AR, Blackwell PG (2006) Revisiting the catastrophic die-off of the urchin Diadema antillarum on Caribbean coral reefs: fresh insights on resilience from a simulation model. Ecol Model 196:131-148

> Murray CB, Evelyn TPT, Beacham TD, Barner LW, Ketcheson JE, Prosperi-Porta L (1992) Experimental induction of bacterial kidney disease in chinook salmon by immersion and cohabitation challenges. Dis Aquat Org 12:91-96

Myers JM, Kope RG, Bryant GJ, Teel DJ and others (1998) Status review of Chinook salmon from Washington, Idaho, Oregon, and California. NOAA Technical Memorandum NMFS-NWFSC-35, US Department of Commerce, Washingtion, DC

Myers MS, Anulacion BF, French BL, Reichert WL and others

Editorial responsibility: Hans Heinrich Janssen, Oldendorf/Luhe, Germany
(2008) Improved flatfish health following remediation of a PAH-contaminated site in Eagle Harbor, Washington. Aquat Toxicol 88:277-288

Pascho RJ, Elliott DG, Achord S (1993) Monitoring of the inriver migration of smolts from two groups of spring chinook salmon, Oncorhynchus tshawytscha (Walbaum), with different profiles of Renibacterium salmoninarum infection. Aquacult Fish Manage 24:163-169

Pearcy WG (1992) Ocean ecology of North Pacific salmonids. University of Washington Press, Seattle, WA

> Pettersen EF, Bjorlow I, Hagland TJ, Wergeland HI (2005) Effect of seawater temperature on leucocyte populations in Atlantic salmon post-smolts. Vet Immunol Immunopathol 106:65-76

Pollard HA II, Flagg TA (2004) Guidelines for use of captive broodstocks in recovery efforts for Pacific salmon. Am Fish Soc Symp 44:333-345

Rannala B, Mountain JL (1997) Detecting immigration by using multilocus genotypes. Proc Nathl Acad Sci USA 94: 9197-9201

- Rhodes LD, Durkin C, Nance SL, Rice CA (2006) Prevalence and analysis of Renibacterium salmoninarum infection among juvenile Chinook salmon Oncorhynchus tshawytscha in North Puget Sound. Dis Aquat Org 71:179-190

Rice CA, Greene CM, Moran P, Teel DJ and others (2011) Abundance, stock origin, and length of marked and unmarked juvenile Chinook salmon in the surface waters of greater Puget Sound. Trans Am Fish Soc 140:170-189

Richter A, Kolmes SA (2005) Maximum temperature limits for Chinook, coho, and chum salmon, and steelhead trout in the Pacific Northwest. Rev Fish Sci 13:23-49

Sanders JE, Pilcher KS, Fryer JL (1978) Relation of water temperature to bacterial kidney disease in coho salmon (Oncorhynchus kisutch), sockeye salmon (O. nerka), and steelhead trout (Salmo gairdneri). J Fish Res Board Can 35:8-11

Sanders JE, Long JJ, Arakawa CK, Bartholomew JL, Rohovec JS (1992) Prevalence of Renibacterium salmoninarum among downstream-migrating salmonids in the Columbia River. J Aquat Anim Health 4:72-75

Seeb LW, Antonovich A, Banks MA, Beacham TD and others (2007) Development of a standardized DNA database for Chinook salmon. Fisheries 32:540-552

Starliper CE, Morrison P (2000) Bacterial pathogen contagion studies among freshwater bivalves and salmonid fishes. J Shellfish Res 19:251-258

> Stentiford GD, Bignell JP, Lyons BP, Feist SW (2009) Sitespecific disease profiles in fish and their use in environmental monitoring. Mar Ecol Prog Ser 381:1-15

Turner SM, Faisal M, DeWoody JA (2007) Zygosity at the major histocompatibility class IIB locus predicts susceptibility to Renibacterium salmoninarum in Atlantic salmon (Salmo salar L.). Anim Genet 38:517-519

> VanderKooi SP, Maule AG (1999) Prevalence of Renibacterium salmoninarum in juvenile spring Chinook salmon at Columbia and Snake river hatcheries, 1993-1996. J Aquat Anim Health 11:162-169

Watts M, Munday BL, Burke CM (2001) Immune responses of teleost fish. Aust Vet J 79:570-574

Submitted: January 17, 2011; Accepted: April 7, 2011

Proofs received from author(s): June 3, 2011 